\title{
农业文化遗产地“三产”融合度评价 以云南红河哈尼稻作梯田系统为例
}

\author{
张永勋 ${ }^{1,2}$, 闵庆文 ${ }^{2,3}$, 徐 明 $^{4}$, 李先德 ${ }^{1}$ \\ (1. 中国农业科学院农业经济与发展研究所, 北京 $100081 ; 2$. 中国科学院地理科学与资源研究所, 北京 \\ 100101;3. 中国科学院大学, 北京 100049;4. 农业农村部国际交流服务中心,北京 100125)
}

\begin{abstract}
摘要: 工业化和城市化过程中,城乡经济差距日益拉大,农村衰落已成为城市化过程中各国面 临的共同问题。2015 年中央政府提出了 “农村一二三产业融合发展”推动农村经济发展的政 策, 引起了众多学科研究者从不同角度开展研究, 但相关研究多以理论探讨为主。农业文化遗 产地作为一个以遗产保护为前提的特殊农村地区, 如何推动一二三产业 (下称 “三产”) 融合发 展, 如何量化 “三产” 融合度, 研究尚待深人。基于对农业文化遗产特点、资源特征以及农业文 化遗产保护要求等方面的分析, 阐释了农业文化遗产地 “三产” 融合发展的概念和内涵, 并构建 了由产业融合度与劳动力融合度组成的农业文化遗产地“三产”融合度评价方法体系及具体核 算方法。以云南红河哈尼稻作梯田系统十大片区所在的 8 个乡镇为对象进行评价, 结果表明, 产业融合度分项指数间越均衡则产业融合度越高; 各乡镇分项指数和产业融合度的数值皆很 小, 有巨大的 “三产” 融合发展空间; 新街镇一二三产业的劳动力融合度领先, 其中第三产业贡 献率最大; 农业文化遗产地 “三产” 的产业融合与劳动力融合有较高的正相关性 $(r=0.67)$, 显著 水平在 $10 \%$ 以下 $(P=0.069<0.1)$ 。推动“三产” 融合发展可以有效促进农民在本地就业, 对于保 护农业文化遗产有着重要意义。
\end{abstract}

关键词: 农业文化遗产;哈尼梯田; 一二三产业融合; 产业融合度;劳动力融合度

在工业化和城市化飞速发展的今天，农业在国民经济中的地位日趋下降，农村地区 经济发展水平日益落后，各国普遍采取通过激发农村地区经济发展内生潜力以缩小城乡 经济差距的措施。发达资本主义国家很早就开始推动农村地区产业融合发展，如自 1850s 英、法、德、美等国开始探索通过农业教育与科研释放农村经济发展潜力的模式 ${ }^{[1-3]}$, 荷 兰实施 “OVO”（将农业科研、教育和推广结合）三位一体农业模式 ${ }^{[4]}$; 20 世纪 50 年代 美国提出通过 Agribusiness 模式来增加农业的经济效益 ${ }^{[5-6]} ; 20$ 世纪 90 年代日本今村奈良 臣提出农村 “六次产业化” 理念增加农业附加值 ${ }^{[7-8]}$ 。中国早在 1990 s 提出了以市场需求 为导向, 以经济效益最大化为目的, 以农业为基础产业向工业、商业、科研、服务业延 伸的综合产业体系 “农业产业化” ${ }^{[9]}$ ，在东部部分地区取得了很好的效果。然而，这一理 论具有地域局限性，许多地区的农村要素与资源并未得到有效开发。2015 年中央一号文 件提出 “推进农村一二三产融合发展”，2016年国务院办公厅发布《关于推进农村一二

收稿日期：2018-07-22；修订日期：2018-11-07

基金项目：云南省红河州委托项目; 农业部国际交流合作项目; 中国农业科学院科技创新工程 (CAAS-ASTIPIAED-2018-06)

作者简介：张永勋（1983- ), 男, 河南光山人, 助理研究员, 主要从事农业文化遗产保护与发展、可持续农业与乡 村发展、生态经济方面的研究。E-mail: zhangyongxun@caas.cn

通讯作者: 闵庆文 (1963-), 男, 江苏徐州人, 研究员, 博士生导师, 主要从事农业文化遗产保护、资源生态安全 与区域可持续发展方面的研究。E-mail: minqw@igsnrr.ac.cn 
三产业融合发展的指导意见》，把农村一二三产业融合（后文用 “三产” 融合表示）发展 提升到了国家政策层面。

推动农村 “三产” 融合发展系列中央文件的相继出台，引起了不同学科研究者从不 同角度展开研究。赵海认为 “三产” 融合指的是各类农业产业组织通过延伸产业链条、 完善利益机制，打破农产品生产、加工、销售相互割裂的状态，形成各环节融会贯通、 各主体和谐共生的良好产业生态 ${ }^{[10]}$ 。苏毅清等认为 “三产” 融合指农林牧副渔等第一产 业的细分产业与第二、第三产业中的细分产业所形成的社会生产的产业间分工在农村实 现内部化 ${ }^{[1]}$ 。姜长云将 “三产” 融合发展理解为通过农村一二三产业间的融合渗透和交 叉重组, 延伸产业链、拓展产业范围和推动产业功能转型, 实现产业发展和发展方式转 变，形成新技术、新业态、新商业模式，带动资源、要素、技术、市场需求在农村的整 合集成和优化重组，甚至农村产业空间布局的调整 ${ }^{[2]}$ 。然而，现有研究多是 “三产” 融 合概念和方式的个人理解，尚没有用定量指标表征 “三产” 融合状态的研究，而这对于 回答 “农村 “三产” 应如何融合”、“农村 “三产” 是否趋向融合发展”的问题至关重要。

农业文化遗产地多分布在偏远的传统农业区，拥有发展二三产业的丰富资源，但是 目前绝大多数的遗产地二三产业发展程度低、经济贫困，同时还面临着遗产保护的任 务, 是传统农业区的典型代表。为此, 本研究以农业文化遗产地作为研究对象, 构建农 业文化遗地 “三产” 融合度评价方法, 并以云南红河哈尼稻作梯田系统为例进行案例研 究, 以期为研究者和管理者提供参考。

\section{1 研究方法与数据来源}

\section{1 研究方法}

\subsection{1 研究思路}

本研究认为的 “三产” 融合实质就是以农产品和农副产品为原材料或工业生产辅助 材料发展第二产业，利用农业的多功能性发展第三产业，利用加工产品进一步发展第三 产业, 并带动物流、仓储、信息通信业发展，通过延长产业链以提高产品附加值，在这 一过程中既解决当地人就业问题，又提高地方经济的发展水平。对于农业文化遗产地而 言，出于对传统农业系统保护的原因，一二、二三、一三产业的融合度必须以第一产业 为基础，即二三产业必须依赖于第一产业提供资源或为第一产业服务。因此，与第一产 业没有关系的二、三产业，如采矿业、建筑业、金属和非金属矿物冶炼和制造业、机械 制造和精密仪器加工等，不应考虑在内。

基于上述考虑，依照《中国国民经济行业分类》（GB/T 4754-2011）标准，理论上标 准中所有与农业相关的行业类型都应纳人农业文化遗产地 “三产” 融合度核算。但由于 县级及以下的行政区，没有相关的行业统计指标，而且不同地区的不同行业发展水平差 异很大，因此，在进行 “三产” 融合度计算时，应遵循 “反映实际，简单易行” 的原 则，可结合研究区已有的统计资料，选取最能代表三次产业发展水平的主要几个行业进 行核算，以表征研究区 “三产” 融合水平。

\subsection{2 评价方法构建}

农业文化遗产地 “三产” 融合状况可用一二三产业的融合度表示。由于保护农业文 化遗产系统是遗产地人们的责任和当地 “三产” 融合发展的重要目标, 因此, 这一特殊 
地区 “三产” 融合度的表征需考虑两个问题：经济发展水平和传统农业的可持续性。在 当前的市场经济背景下，外来资本很容易介人遗产地从事农业经营和二三产业开发，但 是, 外来经营者不了解当地的传统农业生产知识和传统文化，而且他们经营目的是单纯 对经济利益的追求，而没有当地人的故乡情和对遗产保护的责任感，故很难承担起农业 文化遗产保护的角色。因此, 要想让传统农业持续下去, 必需让掌握当地文化和农业生 产技能的本地农民留在家乡从事农业，而让其继续从事农业的唯一途径，就是保证他们 能在本地就业且可获得足以让他们满意的经济收益。从这个角度看, “三产” 融合度应从 产业状况和劳动者本地就业状况两个方面反映，即农业文化遗产地三次产业之间在产业 上的关联程度用 “产业融合度” 表示，劳动力上的渗透程度用 “劳动力融合度” 表示。

(1) 产业融合度的核算

“三产”产业融合度可用第一产业的产品流人第二三产业的比例 $\left(P_{A}\right)$ 、涉农第二产 业在第二产业中的比例（ $\left.P_{I}\right)$ 和涉农第三产业在第三产业中的比例 $\left(P_{S}\right)$ 反映。对于 农业文化遗产地 “三产” 融合而言, $P_{A} 、 P_{I} 、 P_{S}$ 具有同等重要的地位, 故本研究采用 三者的平均值表示第一二三产业融合度 $\left(P_{T}\right)$ 。另外，因不同地区的 $P_{A} 、 P_{I} 、 P_{S}$ 值往 往差别会很大, 为了降低极端值对一二三产业融合度 $\left(P_{T}\right)$ 的影响和强调三者的紧密关 系, 本研究采用三者的几何平均数 $P_{T}$ 表示, 则 $P_{T}$ 的算式可表示为:

$$
P_{T}=\sqrt[3]{P_{A} \times P_{I} \times P_{S}}
$$

其中，第一产业产品流人第二三产业的指数 $\left(P_{A}\right)$, 可用如下公式表示:

$$
P_{A}=\sum_{i}^{n} R_{i} / G
$$

式中： $R_{i}$ 表示第一产业中被第二三产业利用的第 $i$ 种资源增加值； $G$ 表示乡镇生产总值。

涉农第二产业在第二产业中的指数 $\left(P_{I}\right)$, 其计算公式如下:

$$
P_{I}=\sum_{i}^{n} F_{i} / G
$$

式中： $F_{i}$ 表示第二产业中第 $i$ 种依靠农业提供生产要素的工业类型的增加值。

涉农第三产业在第三产业中的指数 $\left(P_{S}\right)$, 其计算公式如下:

$$
P_{S}=\sum_{i}^{n} S_{i} / G
$$

式中： $S_{i}$ 表示第三产业中第 $i$ 种与第一二产业有密切关系的产业类型的增加值。

由于式 (1) 中 $P_{I} 、 P_{S}$ 理论最大值为 1 , 而 $P_{A}$ 的值则有可能大于 1 (农产品加工业 的产业链越长, 该数值越大), 则 $P_{T}$ 数值越大产业融合度越好, 反之产业融合度越低。

(2) 劳动力融合度的核算

对于农业文化遗产地而言，劳动力本地就业状况对其保护有着重要意义。本地就业 率越高，一般当地的产业发展水平越高，而传统农业生产活动和农业系统得到维护的可 能性也越大。遗产地的农民本地就业状况对 “三产” 融合度的指示作用可以通过二三产 业的劳动力吸纳能力反映。农业文化遗产地产业专业化程度差，而且季节性明显，所以 绝大多数劳动力为兼业人员。因此, “三产” 劳动力融合度 $\left(P_{B T}\right)$ 可以用第一二产业劳 动力融合度 $\left(P_{A I}\right)$ 和第一三产业劳动力融合度 $\left(P_{A S}\right)$ 表示, 同式 $(1)$ 的原理, $P_{B T}$ 的表达式可以表示为:

$$
P_{B T}=\sqrt{P_{A I} \times P_{A S}}
$$


其中, 第一二产业劳动力融合指数 $\left(P_{A I}\right)$ 的计算公式为:

$$
P_{A I}=\frac{B_{A I}}{W}
$$

式中： $W$ 乡村总劳动力资源总量； $B_{A I}$ 表示第二产业中涉农企业劳动力数量。

第一三产业劳动力融合指数 $\left(P_{A S}\right)$ 的计算公式为:

$$
P_{A S}=\frac{B_{A S}}{W}
$$

式中: $B_{A S}$ 表示第三产业中涉农企业劳动力数量。

同样地, 由于式 $(5)$ 中 $P_{A I} 、 P_{A S}$ 的理论最大值为 $1, P_{B T}$ 的理论取值范围则为 $0 \sim$ 1 , 则数值越大劳动力融合度越好, 反之劳动力融合度越低。

1.1.3 研究区农产品的二三产业流人比例估算公式调整

农产品加工业及消耗农产品的第三产业对当地的经济和劳动就业显然具有重要贡 献, 故属于 “三产” 融合的重要内容。然而, 因研究区以乡镇为评价单元, 各乡镇没有 对其辖区内的农产品加工企业的投人产出情况进行统计, 缺少直接在本地作为原料进行 加工的农产品数据，故无法按照式（1）计算第二三产业中的农产品增加值占第一产业总 值的比。为此, 本研究采用实地调研估测参数的方式, 对农产品本地加工率进行估算。 相应地也对式 (2) 进行一定的改变, 即第一产业产品流人第二三产业的指数 $\left(P_{A}\right)$ 可 用以下公式计算得出:

$$
\begin{gathered}
P_{A}=\frac{A_{t}}{G} R \\
R=\frac{\sum_{i=1}^{n} \bigotimes_{i} \times m_{i}}{T M}
\end{gathered}
$$

式中: $A_{t}$ 为第一产业生产总值; $R$ 为农产品的二三产业流人率; $\varnothing_{i}$ 为第 $i$ 种农产品流人 二三产业的指数； $m_{i}$ 为第 $i$ 种农产品的年产量（加工产品的再加工需将流人量再次纳人 流人率的计算当中, 这意味着加工业的产业链越长, 农产品的二三产业流入率越高, 即， $R$ 的取值范围为: $+\infty>R>0)$ 。 $T M$ 为乡镇年产农产品的总重量。

\section{2 研究区概况}

研究区包括红河县甲寅镇和宝华镇, 元阳县新街镇、攀枝花乡和牛角寨乡, 绿春县 三猛乡, 以及金平县阿得博乡和马鞍底乡 8 个乡镇, 是哈尼梯田十大片区所在乡镇（图 1）。目前，这些乡镇还是典型的传统农业地区，第二三产业包含的涉农产业类型十分有 限。据调查及统计资料显示，第二产业包括的类别主要有建筑业、采矿业、发电业、农 副食品加工业、酒、饮料与茶制造业、木材加工及木、竹、藤、棕、草制品业，其中， 农副食品加工业、酒、饮料与茶制造业、木材加工及木、竹、藤、棕、草制品业是与农 业有关的产业类型; 第三产业包括的类别主要有道路运输业、邮政业、电信和其他信息 传输服务业、批发业、零售业、住宿业和餐饮业, 其中道路运输业、邮政业、住宿业和 餐饮业是主要涉农第三产业。

\section{3 数据来源}

由于乡镇级的行业统计分类数据缺乏, 采用乡镇统计数据和第一手调研数据相结合 的方式进行研究。第一二三产业的经济数据和劳动就业人口数据主要源于 8 个乡镇的 《2014年农村经济统计综合年报表》和《2014年乡镇企业（含个体工商户）主要经济指 


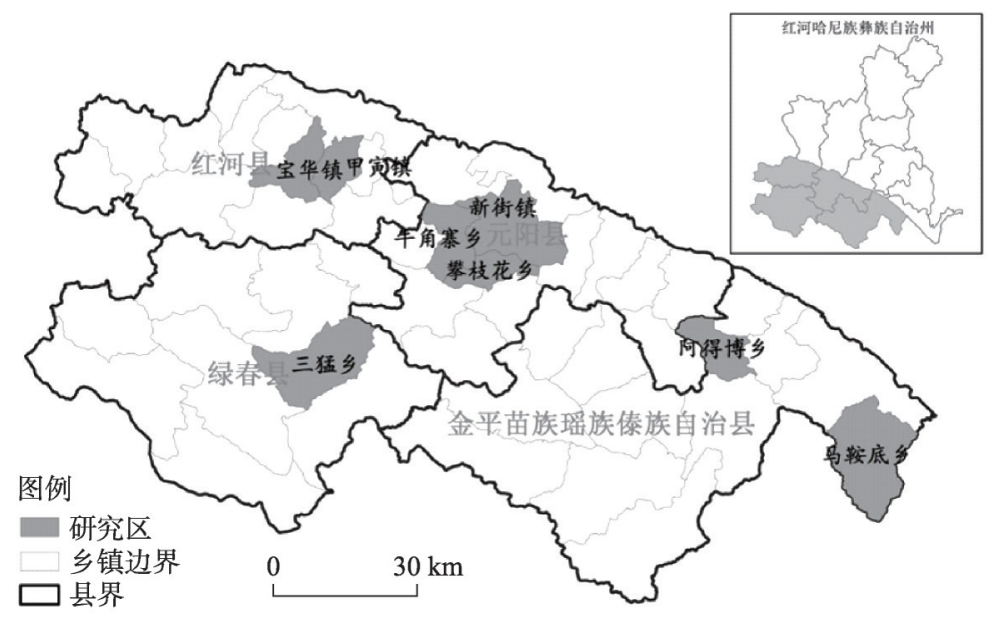

图 1 研究区评价单元及其空间分布

Fig. 1 The evaluated cells and their distribution of the studied towns

标年报总量汇总表》，以及 2015 年 4-5 月份、7-8 月份和 2016 年 8 月上中旬对 8 个乡镇政府 相关工作人员、农户、餐馆经营者访谈获得。由于企业投人产出、行业分类统计数据缺 乏，本研究中，第一产业产品流人二三产业的指数用第一产业的农产品加工率替代（基 于实地访谈和问卷调查估算得出），第二产业中涉农第二产业指数则用农产品加工业占第 二产业总值的比例表示，第三产业中涉农第三产业指数用住宿和餐饮业产值占第三产业 总值比例来表示（因为游客进人消费是第三产业获得外部资金的主要途径）。

\section{2 结果分析}

\section{1 研究区各乡镇社会经济特征}

表 1 反映了 8 个乡镇的基本经济状况。可以看出，新街镇无论是经济总产值还是其他 各项经济指标都明显高于其他乡镇，特别是第三产业的比例相当高，达到 $47.9 \%$; 其次 红河县甲寅镇和元阳县牛角寨乡的经济总量较高，二者在第一二产业上具有一定的相似 性；而金平县阿得博乡和马鞍底乡的经济总产值相对其他乡镇明显较低，第一产业所占 比例比较大，二者在经济结构上具有较高的相似性。总体而言，除新街镇外，其他各乡 镇农业产值在总产值占绝对优势，可见它们皆是以农业为主要产业的乡镇。

从当地劳动人口就业看（表 2)，新街镇的乡村就业人口数量及其他各类别的就业人 口数量均明显高于其他乡镇，这是因为其人口总量显著高于其他乡镇，但是在乡村劳动 力资源占比上，处于中间水平; 攀枝花乡和三猛乡从事第一产业的人口数量较多，且第 一产业劳动人口比例遥遥领先于其他乡镇, 分别达到了 $95.8 \%$ 和 $94.8 \%$, 而且三猛乡二二 三产业人口比例之和大于 1 , 反映该乡外出务工的劳动力不多，不少劳动力在家兼营二 三产业; 甲寅镇的第一产业就业人口占比相对较少，但第三产业就业人口占比高。从一 二三产业人口比例之和看，甲寅镇、牛角寨乡和马鞍底乡 3 个乡镇别分为 $82.4 \%$ 、 $73.3 \%$ 和 $80.1 \%$, 可知这 3 个乡外出务工的劳动力比较多。

\section{2 农产品的二三产业流入比例的估算}

由于各乡镇种植的农作物种类很多，为简化计算，本研究仅取各乡镇年产量在 $100 \mathrm{t}$ 
表 1 各乡镇经济概况及涉农第二三产业的状况

Table 1 The economic situations of towns and the secondary and tertiary industrial situations related with agriculture

\begin{tabular}{|c|c|c|c|c|c|c|c|c|c|}
\hline \multirow[b]{2}{*}{ 地名 } & \multirow{2}{*}{$\begin{array}{l}\text { 总产值 } \\
\text { /万元 }\end{array}$} & \multicolumn{2}{|c|}{ 第一产业 } & \multicolumn{2}{|c|}{ 第二产业 } & \multicolumn{2}{|c|}{ 第三产业 } & \multirow{2}{*}{$\begin{array}{c}\text { 农产品 } \\
\text { 加工业 } \\
\text { /万元 }\end{array}$} & \multirow{2}{*}{$\begin{array}{l}\text { 住宿及 } \\
\text { 餐饮业 } \\
\text { /万元 }\end{array}$} \\
\hline & & 产值 & $\begin{array}{c}\text { 占比 } \\
1 \%\end{array}$ & $\begin{array}{l}\text { 产值 } \\
\text { /万元 }\end{array}$ & $\begin{array}{c}\text { 占比 } \\
1 \%\end{array}$ & $\begin{array}{l}\text { 产值 } \\
\text { /万元 }\end{array}$ & $\begin{array}{c}\text { 占比 } \\
1 \%\end{array}$ & & \\
\hline 甲寅镇 & 20065 & 14219 & 70.9 & 3511 & 17.5 & 2335 & 11.6 & 224 & 213 \\
\hline 宝华镇 & 18661 & 14345 & 76.9 & 854 & 4.6 & 3462 & 18.6 & 153 & 431 \\
\hline 新街镇 & 108846 & 31640 & 29.1 & 25100 & 23.1 & 52106 & 47.9 & 3608 & 14900 \\
\hline 牛角寨乡 & 25150 & 18876 & 75.1 & 5114 & 20.3 & 1160 & 4.6 & 2345 & 68 \\
\hline 攀枝花乡 & 10516 & 8545 & 81.3 & 840 & 8.0 & 1131 & 10.8 & 246 & 160 \\
\hline 三猛乡 & 17955 & 15467 & 86.1 & 1743 & 9.7 & 745 & 4.1 & 503 & 102 \\
\hline 阿得博乡 & 7326 & 6226 & 85.0 & 400 & 5.5 & 700 & 9.6 & 128 & 230 \\
\hline 马鞍底乡 & 9180 & 7879 & 85.8 & 292 & 3.2 & 1009 & 11.0 & 130 & 324 \\
\hline
\end{tabular}

表 2 各乡镇就业及二三产业中涉农产业从业人数

Table 2 The number of employees in the secondary and tertiary industries related with the agriculture

\begin{tabular}{|c|c|c|c|c|c|c|c|c|c|}
\hline \multirow[b]{2}{*}{ 地名 } & \multirow{2}{*}{$\begin{array}{c}\text { 乡村从 } \\
\text { 业人数 } \\
\text { 人 }\end{array}$} & \multicolumn{2}{|c|}{ 第一产业 } & \multicolumn{2}{|c|}{ 第二产业 } & \multicolumn{2}{|c|}{ 第三产业 } & \multirow{2}{*}{$\begin{array}{c}\text { 二产涉农 } \\
\text { 产业人数 } \\
\text { /人 }\end{array}$} & \multirow{2}{*}{$\begin{array}{c}\text { 三产涉农 } \\
\text { 产业人数 } \\
\text { /人 }\end{array}$} \\
\hline & & $\begin{array}{l}\text { 人数 } \\
\text { /人 }\end{array}$ & $\begin{array}{c}\text { 占比 } \\
1 \%\end{array}$ & $\begin{array}{l}\text { 人数 } \\
\text { 人 }\end{array}$ & $\begin{array}{c}\text { 占比 } \\
1 \%\end{array}$ & $\begin{array}{l}\text { 人数 } \\
\text { 人 }\end{array}$ & $\begin{array}{c}\text { 占比 } \\
1 \%\end{array}$ & & \\
\hline 甲寅镇 & 15346 & 8654 & 56.4 & 910 & 5.9 & 3087 & 20.1 & 616 & 18 \\
\hline 宝华镇 & 15430 & 12265 & 79.5 & 274 & 1.8 & 1582 & 10.3 & 23 & 52 \\
\hline 新街镇 & 43233 & 29933 & 69.2 & 3760 & 8.7 & 6765 & 15.6 & 696 & 2000 \\
\hline 牛角寨乡 & 21986 & 14153 & 64.4 & 513 & 2.3 & 1454 & 6.6 & 671 & 86 \\
\hline 攀枝花乡 & 13128 & 12578 & 95.8 & 107 & 0.8 & 499 & 3.8 & 41 & 22 \\
\hline 三猛乡 & 14965 & 14190 & 94.8 & 835 & 5.6 & 986 & 6.6 & 30 & 31 \\
\hline 阿得博乡 & 9029 & 7078 & 78.4 & 558 & 6.2 & 1163 & 12.9 & 52 & 44 \\
\hline 马鞍底乡 & 12041 & 8813 & 73.2 & 199 & 1.7 & 635 & 5.3 & 20 & 86 \\
\hline
\end{tabular}

以上的农产品，即农产品总量为年产 $100 \mathrm{t}$ 以上农产品的总和（表 3)。据调查，哈尼梯田 地区直接在本乡镇进行加工的农产品主要包括：大米加工（稻谷去壳）、米粉加工、肉类 加工、棕丝加工、茶加工, 农产品直接参与第三产业的方式主要为餐饮业。哈尼梯田地 区由于稻田面积有限, 收获的稻谷仅能维持自给, 有些农户即使有剩余, 一般将稻谷加 工成大米出售, 因此, 稻谷的本地加工率（稻谷加工成大米，出米率约为 $75 \%$ ）为 $100 \%$ 。米线是哈尼梯田地区人们最常吃的主食之一，当地人早餐基本为米线，中午和晚 上也有食用, 而米线加工也主要在本乡镇完成。据实地调查估计, 大米加工成米线的比 率约为 $35 \%$, 受旅游业影响，新街镇米线消耗率高于其他乡镇，故取加工率为 $60 \%$ 。考 虑到农户消费的肉类主要从集市购买, 所以统计数据中肉类产量皆视为本地加工, 故取 肉类本地加工率为 $100 \%$ 。除上述各乡镇共有的加工业以外，甲寅镇还拥有棕丝加工产业 (据调查估计, 棕片本地加工率约为 $40 \%$ ), 受旅游业的带动, 各乡镇直接流人餐饮业的 蔬菜比例也各不相同（具体参数见表4）。各乡其他农产品都以初级农产品的形式出售, 故二三产业流人率计为 0 。

利用式（9）计算结果表明（图 2), 牛角寨的农产品二三产业流入率最高, 攀枝花 乡和三猛乡略低于前者, 但这 3 个乡农产品的二三产业流入率均在 $50 \%$ 以上。马鞍底乡 
表 32014 年各乡镇主要农产品产量

Table 3 The yields of agricultural product in each town in 2014

(t)

\begin{tabular}{lcccccccccccccccc}
\hline 地名 & 总质量 & 粮食 & $\begin{array}{c}\text { 其中, } \\
\text { 水稻 }\end{array}$ & 蔬菜 & 甘蔗 & 棕片 & 肉类 & 木薯 & 草果 & 核桃 & 茶叶 & 花生 芭蕉芋 青饲料 香蕉 \\
\hline 甲寅 & 66027 & 10290 & 6036 & 5849 & 17570 & 27025 & 5293 & - & - & - & - & - & - & - & - \\
宝华 & 157359 & 11100 & 7274 & 16986 & 16642 & 4587 & 2844 & 103200 & 1000 & 1000 & - & - & - & - & - \\
新街 & 70890 & 28215 & 12521 & 1257 & 14559 & - & 8406 & 17164 & 1289 & - & - & - & - & - & - \\
牛角寨 & 33052 & 16855 & 10577 & 4229 & 6325 & - & 5343 & - & - & - & - & - & - & - & 300 \\
攀枝花 & 20642 & 9202 & 5654 & 376 & 1385 & - & 3247 & 5629 & & - & - & - & 804 & - & - \\
三猛 & 19139 & 12333 & 4720 & 2130 & 276 & - & 2926 & 106 & 248 & - & 766 & 228 & 125 & - & - \\
阿得博 & 25951 & 6790 & 4565 & 1116 & 16180 & - & 1865 & - & - & - & - & - & - & - & - \\
马鞍底 & 25604 & 10519 & 6564 & 1147 & - & - & 2604 & 2600 & & - & 720 & - & - & 1112 & 601 \\
\hline
\end{tabular}

表 42014 年各乡镇各类农产品的二三产业流入率估值

Table 4 Evaluated values of the rate of different agricultural products inflowing the secondary and tertiary industries in the towns in 2014

\begin{tabular}{cccccc}
\hline 地名 & 大米 $/ \%$ & 米线 $/ \%$ & 棕丝 $/ \%$ & 肉类/\% & 蔬菜/\% \\
\hline 甲寅镇 & 100 & 35 & 40 & 100 & 5 \\
宝华镇 & 100 & 35 & - & 100 & 10 \\
新街镇 & 100 & 60 & - & 100 & 25 \\
牛角寨乡 & 100 & 35 & - & 100 & 1 \\
攀枝花乡 & 100 & 35 & - & 100 & 10 \\
三猛乡 & 100 & 35 & - & 100 & 1 \\
阿得博乡 & 100 & 35 & - & 100 & 1 \\
马鞍底乡 & 100 & 35 & - & 100 & 15 \\
\hline
\end{tabular}

的农产品二三产业流人率为 $45 \%$ 以上，甲寅镇和新街镇农产品的二三产业流人率均高于 $30 \%$ 。阿得博乡和宝华镇农产品的二三产业流人率较低，在 $30 \%$ 以下。

\section{3 “三产”产业融合度}

\subsection{1 产业融合度}

利用式（8）、式（3）和式（4）分别算出，第一产业产品流人第二三产业的指数 $\left(P_{A}\right)$ 、第二产业中涉农二产指数 $\left(P_{I}\right)$ 和第三产业中涉农三产的指数 $\left(P_{S}\right)$ 。再根据 式 (1) 算出一二三产业的产业融合度 $\left(P_{T}\right)$ 。如表 5 所示，新街镇 “三产” 的产业融合 度最高, 为 0.077 , 其次为马鞍底乡、攀枝花乡和阿得博乡, 均高于 0.05 , 其他乡镇相对 较低。从分项指标看，第一产业产品流人第二三产业的指数为三猛乡最高，牛角寨乡、 攀枝花乡和马鞍底乡次之, 宝华镇的这一比例最低; 从第二产业中涉农二产的指数看, 牛角寨乡的比例仍然是最高的, 其次是新街镇, 第三是三猛乡, 其他乡比例很低; 在第 三产业中涉农三产指数方面，新街镇拥有明显的领先优势，其次为马鞍底乡和阿得博 乡, 牛角寨乡的比例最低, 仅为 0.003 。将三个指数横向对比可以看出, 第一产业产品流 人第二三产业的指数对 “三产” 产业融合度的贡献率最高, 明显要高于第二产业中涉农 二产指数和第三产业中涉农三产指数的贡献率，新街镇因为三个指数间比较均衡，所以 产业融合度较高。 
但分项指数和产业融合度的数值反映 出这 8 个乡镇属于以农业为主要产业的典 型乡镇，二三产业基本处于未发展状态。 2.3.2 第一二三产业的劳动力融合度

利用式（6）和（7）可分别算出，第 二二产业劳动力融合指数 $\left(P_{A I}\right)$ 和第一 三产业劳动力融合指数 $\left(P_{A S}\right)$, 再利用 式（5）算出第一二三产业的劳动力融合 度 $\left(P_{B T}\right)$ 。表 5 显示, 在劳动力融合度方 面, 新街镇最高, 远高于其他乡镇, 其次 为牛角寨乡, 而其他乡镇比较低。从分项 指数看, 甲寅镇一二产业劳动力融合指数 最高, 其次为牛角寨乡, 再次为新街镇, 而其它乡镇很低，表明甲寅镇、牛角寨乡

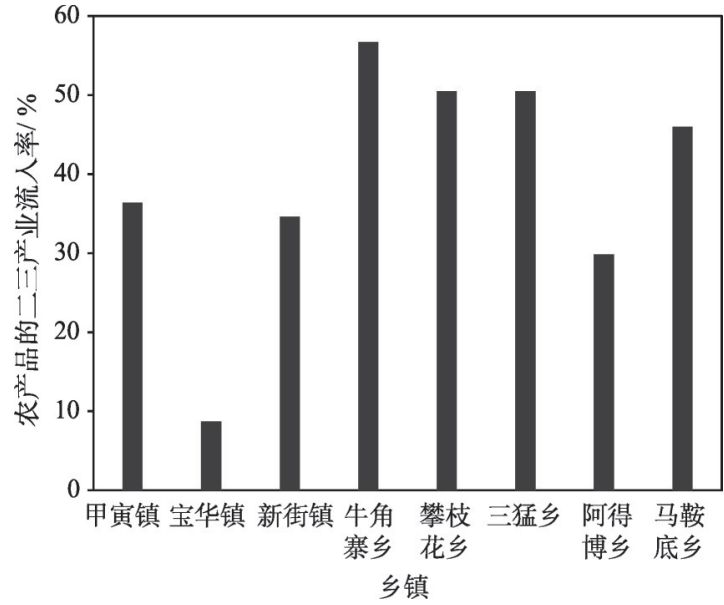

图 2 各乡镇农产品二三产业流人率

Fig. 2 The total rate of agricultural products inflowing the secondary and tertiary industries in the towns in 2014 和新街镇兼营第二产业的农民比例相对较

高, 但由于他们的融合度也均低于 0.05 , 说明农民兼职第二产业的人数相当有限; 而在 一三产业劳动力融合指数方面, 新街镇指数最高, 其他乡镇都非常低, 这表明, 新街镇 第三产业吸纳了相对较多的农民兼业，而其他乡镇从事第三产业的农民非常少。然而， 无论是就业的分项指数还是劳动力融合度的数值, 最高值也仅仅 0.046 , 说明这 8 个乡镇 的二三产业吸纳农民兼业的能力非常低。

\section{表 5 “三产” 产业融合度和劳动力融合度及分项指数}

Table 5 The total industrial integration degree and the total labor integration degree among the three industries and the sub-indices of the two indices

\begin{tabular}{|c|c|c|c|c|c|c|c|}
\hline \multirow{2}{*}{ 乡镇 } & \multicolumn{4}{|c|}{ 产业融合度 } & \multicolumn{3}{|c|}{ 劳动力融合度 } \\
\hline & $P_{A}$ & $P_{I}$ & $P_{S}$ & $P_{T}$ & $P_{A I}$ & $P_{A S}$ & $P_{B T}$ \\
\hline 甲寅镇 & 0.258 & 0.011 & 0.011 & 0.031 & 0.040 & 0.001 & 0.007 \\
\hline 宝华镇 & 0.067 & 0.008 & 0.023 & 0.023 & 0.001 & 0.003 & 0.002 \\
\hline 新街镇 & 0.101 & 0.033 & 0.137 & 0.077 & 0.016 & 0.046 & 0.027 \\
\hline 牛角寨乡 & 0.426 & 0.093 & 0.003 & 0.048 & 0.031 & 0.004 & 0.011 \\
\hline 攀枝花乡 & 0.410 & 0.023 & 0.015 & 0.053 & 0.003 & 0.002 & 0.002 \\
\hline 三猛乡 & 0.435 & 0.028 & 0.006 & 0.041 & 0.002 & 0.002 & 0.002 \\
\hline 阿得博乡 & 0.253 & 0.017 & 0.031 & 0.052 & 0.006 & 0.005 & 0.005 \\
\hline 马鞍底乡 & 0.395 & 0.014 & 0.035 & 0.058 & 0.002 & 0.007 & 0.003 \\
\hline
\end{tabular}

\section{4 产业融合度与劳动融合度的关系}

由表 5 中 $P_{T}$ 列和 $P_{B T}$ 列数值可以看出, 8 个乡镇产业融合度与劳动融合度上的变化 趋势具有一定的相似性，相关分析表明，二者具有较高的正相关性 $(r=0.67)$ ，显著水平 在 0.1 以下 $(P=0.069<0.1)$, 这说明农业文化遗产地的产业融合发展可以带动农业劳动力 向二三产业渗透，解决农闲时期劳动力的本地就业问题，但是不同的二三产业类型经济 贡献能力和劳动力吸纳能力并不一致。这也为当地政府和相关管理部门指出，利用农业 
产出物作为资源发展第二三产业, 具有解决当地劳动力农闲就业和留住农民继续从事传 统农业生产的作用，从而促进梯田及其传统文化的保护。但也必须注意，要根据自身的 资源特征和产业特点选择正确的产业发展方向。

由表 5 还可以看出, 攀枝花乡和马鞍底乡的产业融合度与其劳动力融合度比较, 有 一个明显的上升波动，而这两个乡属于旅游业发展相对较快的乡，攀枝花乡的老虎嘴景 区属于元阳梯田景区的核心景点之一，马鞍底乡拥有蝴蝶谷、标水岩民俗文化村、五台 山瀑布群、平河高山草甸草原等景点, 旅游业发展迅速。这说明旅游业推动产业融合速 度快于劳动力融合速度, 这可能与旅游活动发生地具有集聚性特点以及与当前旅游经济 活动主要为餐饮和住宿业有关。各地的旅游业虽然迅速发展，但是由于餐饮和住宿式的 旅游经济，导致可以直接参与到旅游业中的人数十分有限。

\section{3 结论与讨论}

\section{1 结论}

（1）在哈尼梯田重点保护区所在的 8 个乡镇中，新街镇 “三产” 的产业融合度和劳 动力融合度分项指标相对较高且较均衡, “三产” 的产业融合度和劳动力融合度皆远高于 其他乡镇, 呈 “一镇独大” 之势。总体而言, 各乡镇的产业融合度和劳动力融合度都很 低，表明各乡镇二三产业发展水平很低，解决农民本地就业的能力亦非常有限，也意味 着各乡镇 “三产”融合发展有巨大的发展空间。

（2）农业文化遗产地 “三产” 的产业融合与劳动力融合呈正相关关系，推动 “三 产” 融合发展可以有效地促进农民在本地就业，对于农业文化遗产系统的保护具有重要 意义。在推动遗产地产业发展时，应将高端复合农业和多功能农业、农产品加工业、旅 游业等一二三产业有机结合，协同发展，更有利于本地农民就业，从而有助于本土农民 对农业文化遗产系统的维持和保护。

\section{2 讨论}

\subsection{1 哈尼梯田 8 个乡镇的“三产”融合度及成因}

在 “三产” 的产业融合度方面，新街镇远高于其他乡镇。总体而言，各乡镇的一产 产品流人二三产业的指数对 “三产” 产业融合度的贡献率最高, 明显要高于涉农二产在 第二产业中的指数和涉农三产在第三产业中的指数的贡献率。新街镇三个指数间相对较 均衡, 产业因而融合度较高。其原因在于新街镇的旅游发展带动了加工业、住宿业和餐 饮业的发展，三次产业结构相对比较协调，尤其是第三产业发展水平较高。各乡镇分项 指数和产业融合度的数值很小, 意味着各乡镇 “三产” 融合度处于极低发展水平, 有巨 大的发展空间。

在 “三产” 的劳动力融合度方面, 新街镇 “三产” 劳动力融合度远高于其他乡镇, 较其他乡镇解决了更多的农民在本地就业。甲寅镇和牛角寨乡的一二产业劳动力融合指 数明显高于其他乡镇, 其原因在于甲寅镇的棕㭣和竹产品加工及传统农具加工, 牛角寨 的米加工、茶叶加工等第二产业吸纳兼业农民的能力相对较强。新街镇的一三产业融合 指数最高, 主要原因是新街镇的哈尼梯田坝达片区和多依树片区作为元阳梯田的核心景 区已被广泛宣传, 旅游人数呈暴发性增长, 当地餐饮业和住宿业吸纳农民兼业具有较强 
的优势。然而, 分项指数和劳动力融合度的数值都非常小, 说明目前各乡镇解决农民本 地就业的能力非常有限。

\subsection{2 一二三产业融合度评价方法的讨论}

本研究以农业文化遗产地作为研究对象，因而在评价方法的构建上，首先考虑了遗 产保护问题, 把本地就业作为一个极为重要的因素。其次, 遗产地农业景观是重要的保 护对象, 发展第二三产业是推动地方经济的主要引擎, 三次产业缺一不可, 故将一二、 二三、一三产业融合度和一二与一三产业劳动力融合度分别赋予同等的重要性, 进行 “三产” 融合度的核算。由于研究区的城镇化率极低，农民兼业是绝大多数农业文化遗产 地就业的共同特征, 因而在劳动力融合度上主要考虑劳动力在一二、一三产业上的融合 度，指向性较明确。

本文的研究区属典型的农业区，除满足本地区基本生活需要的简单加工业、零售业 和运输业外，很少有其他二三产业。近几年政府推动和旅游业发展带动下的品牌化农产 品加工业, 餐饮和住宿等旅游接待业快速发展是二三融合发展的重要标志, 所以本研究 选择了农业品加工业, 餐饮和住宿产值分别指示二三产业发展水平。对于其他农村地 区，应根据不同乡镇特点，抓住能反映 “三产” 融合水平的主要产业类型，适当调整评 价指标。此外, 由于我国乡镇级的统计工作非常薄弱, 获取数据非常困难, 第一产业数 据主要基于实地调研的估测，评价结果与客观情况可能会存在一些偏差，这也意味着建 立乡镇级一致的统计口径是未来农业文化遗产地监测评估工作必需考虑的问题。总体而 言, 本研究更重要的意义在于为 “三产” 融合度研究提供一种定量评价方法的参考。

3.2.3 一二三产业融合度研究对农业文化遗产保护的意义

本研究表明，产业的不均衡发展会导致 “三产”融合度较低，“三产”融合发展可以 有效地促进农民在本地就业。就具体产业类型而言，旅游业和加工业的发展既可带动二 三产业的快速发展，也可吸纳大量的劳动力，留住本土居民，对保护农业文化遗产有积 极作用。与此同时，旅游业通过带动当地特色农事活动、农耕景观、农耕文化的开发， 可提高当地居民的民族文化自豪感和文化自觉意识 ${ }^{[13-14]}$ ，但如果管理不当，旅游业也会带 来景观破坏等负面影响 ${ }^{[15-17]}$ 。加工业通过延长产业链条、创造更多的就业岗位, 解决更多 本地人季节性就业问题，从而加强当地社会结构的稳定性和巩固文化的传承机制 ${ }^{[18]}$ 。所 以，未来哈尼梯田的 8 个乡镇应在科学管理前提下，根据自己的农产品和景观资源优 势, 大力发展特色旅游业和农产品加工业。特别应当注意的是, 由于餐饮业和住宿业对 地理区位敏感，主要分布于景区附近，因而需在发展旅游业的同时，也要推动对区位要 求低的农产品加工业和高端品牌农业, 实现一二三产业融合发展, 同时解决遗产地产业 在空间上不均衡发展问题。

\section{参考文献(References):}

[1] CASTONGUAY S. The transformation of agricultural research in France: The introduction of the American system. Minerva, 2005, 43(3): 265-287.

[2] BRASSLEY P. Agricultural research in Britain, 1850-1914: Failure, success and development. Annals of Science, 1995, 52(5): 465-480.

[3] EJETA G. Revitalizing agricultural research for global food security. Food Security, 2009, 1(4): 391-401. 
[4] SPIERTZ J H J, KROPFF M J. Adaptations of knowledge systems to changes in agriculture and society: The case of the Netherlands. Njas Wageningen. Journal of Life Sciences, 2011, 58(1-2): 1-10.

[5] DAVIS J H, GOLDBERG R A. "A concept of agribusiness" division of research, graduate school of business administration, Harvard University, Boston, 1957, 136. American Journal of Agricultural Economics, 1957, 39(4): 1042-1045

[6] RICKETTS C, RICKETTS K. Agribusiness Fundamentals and Applications. America: Delmar Cengage Learning, 2008: 4-5.

[7] 姜长云. 日本的“六次产业化”与我国推进农村一二三产业融合发展. 农业经济与管理, 2015, (3): 5-10. [JIANG C Y. "The Sixth-industrialization for Agriculture" in Japan and promoting the industrial integration-development among rural first industry, second industry, and the third industry in China. Agricultural Economics and Management, 2015, (3): 510.]

[8] NAKANO K. The "sixth industrialization" for Japanese agricultural development. Journal of Ritsumeikan University, 2014, 63: 314-326

[9] 牛若峰.农业产业一体化经营的理论与实践. 北京: 农业科技出版社, 1998. [NIU R F. Agricultural Industry Integration Management Theory and Practices. Beijing: China Agricultural Science and Technology Press, 1998.]

[10] 赵海. 论农村一二三三产融合发展. 农村经营管理, 2015, (7): 26-29. [ZHAO H, Integration development of industries in rural villages. Rural Management and Administration, 2015, (7): 26-29.]

[11] 苏毅清, 游玉婷, 王志刚. 农村一二三产业融合发展: 理论探讨、现状分析与对策建议. 中国软科学, 2016, (8): 1728. [SU Y Q, YOU Y T, WANG Z G. Convergence development of primary, secondary and tertiary industries: Theoretical discussion, situation analysis and suggestions. China Soft Science, 2016, (8): 17-28.]

[12] 姜长云. 推进农村一二三产业融合发展新题应有新解法. 中国发展观察, 2015, (2): 18-22. [JIANG Y C. A new solution for the new topic of promoting industrial integration development. China Development Observation, 2015, (2): 1822.]

[13] 徐义强, 李凯冬. 农业文化遗产红河哈尼梯田保护与开发刍议. 农业考古, 2013, (1): 279-281. [XU Y Q, LI K D. Protection and development of Hani terraced agricultural cultural heritage in Honghe county. Agricultural Archaeology, 2013, (1): 279-281.]

[14] 张建国, 何方, 肖胜和, 等. 基于农业文化遗产保护的江南梯田旅游发展探索: 以浙江梅源梯田为例. 中南林业科技 大学学报, 2011, 31(3): 47-53. [ZHANG J G, HE F, XIAO S H, et al. Tourism development for terraced fields in the regions south of the Yangtze River from the perspective of agricultural heritage preservation: Taking Meiyuan terraced fields of Zhejiang as case example. Journal of Central South University of Forestry \& Technology, 2011, 31(3): 47-53.]

[15] 韩秀记. 生存与发展: 民俗村的二难选择: 云南民俗村调查. 社会科学研究, 2010, (3): 101-106. [HAN X J. Survival and development: Conflicting choice of folk village: A survey on folk villages in Yunnan province. Social Science Research, 2010, (3): 101-106.]

[16] 宗路平, 角媛梅, 李石华, 等. 哈尼梯田遗产区乡村聚落景观及其演变: 以云南元阳全福庄中寨为例. 热带地理, 2014, 34(1): 66-75. [ZONG L P, JIAO Y M, LI S H, et al. The rural settlement landscape and its evolution in Hani rice terrace culture landscape areas: A case study of the Quanfuzhuang middle village, Yuanyang county, Yunnan. Tropical Geography, 2014, 34(1): 66-75.]

[17] 杨伦, 刘某承, 闵庆文, 等. 哈尼梯田地区农户粮食作物种植结构及驱动力分析. 自然资源学报, 2017, 32(1): 26-39. [YANG L, LIU M C, MIN Q W, et al. An analysis on crop choice and its driving factors in Hani Rice Terraces. Journal of Natural Resources, 2017, 32(1): 26-39.]

[18] 张永勋, 闵庆文. 稻作梯田农业文化遗产系统保护研究综述. 中国生态农业学报, 2016, 24(4): 460-469. [ZHANG Y $\mathrm{X}, \mathrm{MIN} \mathrm{Q}$ W. A review of conservation of rice terraces as agricultural heritage systems. Chinese Journal of Eco-agriculture, 2016, 24(4): 460-469.] 


\title{
The evaluation of industrial integration level of important agricultural heritage sites: A case study of Yunnan Honghe Hani rice terraces
}

\author{
ZHANG Yong-Xun ${ }^{1,2}$, MIN Qing-wen ${ }^{2,3}$, XU Ming ${ }^{4}$, LI Xian-de ${ }^{1}$ \\ (1. Institute of Agricultural Economics and Development, Chinese Academy of Agricultural Sciences, Beijing \\ 100081, China; 2. Institute of Geographic Sciences and Natural Resources Research, Chinese Academy of \\ Sciences, Beijing 100101, China; 3. University of Chinese Academy of Sciences, Beijing 100049, China; 4. \\ Center of International Cooperation Service, Ministry of Agriculture and Rural Affairs, Beijing 100125, China)
}

\begin{abstract}
With industrialization and urbanization, the economic gap between rural areas and urban areas is widening. The rural decline has become a problem facing most of the countries. Under this background, the policy of industrial integration development was proposed by the central government of China, aiming at propelling rural economic development. The policy attracted researchers from different disciplines to conduct research from different perspectives. However, most studies have just explored the theories of industrial integration in rural areas, and the quantified case studies are still hardly found. Especially for the Important Agricultural Heritage System (IAHS) Sites as a special rural area, how to promote the development of industrial integration and how to quantify the integration level among primary, secondary and tertiary industries is poorly documented. Thus, in this study, considering the characteristics, resource features and protection demands of IAHS sites, we proposed the concept and connotation of industrial integration development in IAHS sites, and set up an evaluation methodology consisting of industrial integration degree (IID) and labor integration degree (LID) and calculation methods. Taking the eight towns in the Honghe Hani rice terraced systems site, Yunnan as an example, we evaluated the IID and LID of each town. The results are shown as follows. The more balance among the sub-indices of IID and LID of each town, the higher the industrial integration level; all the sub-indices of IID and LID of each town are very small, and a huge development space exists for every town. In the eight towns, Xinjie Township has a highest IID and LID due to the biggest contribution from the tertiary industry; a highly positive correlation is between the IID and the LID of each township $(r=0.67)$, which is below $10 \%$ in significance level $(P=0.069<0.1)$. In conclusion, in IAHS sites, integrated industrial development can enhance the employment percentage of local people.
\end{abstract}

Keywords: agricultural heritage systems; Hani terraces; industrial integration; industrial integration degree; labor integration degree 